Studia Anglica Posnaniensia 52(1), 2017

doi: 10.1515/stap-2017-0003

\title{
CLIPPED WINGS AND THE GREAT ABYSS: COGNITIVE STYLISTICS AND IMPLICATURES IN ABIEZER COPPE'S 'PROPHETIC' RECANTATION
}

\author{
DANIELE BORGOGNI
}

University of Turin, Italy*

\begin{abstract}
In this article, two major paradigms within cognitive stylistics, the Conceptual Metaphor Theory (CMT) and the Conceptual Integration Theory (CIT), are applied as largely complementary approaches to discuss the scope and implicatures of the central metaphorical image of Copp's Return to the wayes of Truth (1651), a text written by one of the most famous radical preachers of the Civil War period as a plea to be released from prison. The article will focus on how the linguistic and cultural contexts of Coppe's prophetic writing, in their interaction with the dynamic conceptual relationships of a conceptual integration network, open up new possibilities of perspectivizing and insinuating radically different meanings and implicatures: the use of blends in Coppe's text has a direct effect on the structure of the analogies that can be made between mental spaces, thereby triggering new meaning effects, supplementary symbolizing patterns, and unpredictable perlocutionary effects.
\end{abstract}

Keywords: conceptual metaphor; blending; implicature; seventeenth-century religious radicalism; Abiezer Coppe

\section{Introduction}

The article $^{1}$ discusses the mental processing and the ideological implicatures triggered by the presence of blends in Copp's Return to the wayes of Truth $(C R)$, a dramatic recantation written in jail by the radical preacher Abiezer Coppe and published in 1651.

\footnotetext{
* Department of Humanities, University of Turin, Via S. Ottavio 20, 10124 Turin, Italy, email: daniele.borgogni@unito.it

1 A shorter version of this article was presented at the Advances in Metaphor Studies International Conference in Genoa (2016).
} 
The analysis will rely on two major paradigms within the cognitive approach, the Conceptual Metaphor Theory (CMT) and the Conceptual Integration Theory (CIT) ${ }^{2}$ considering them as largely complementary perspectives, in the wake of such studies on seventeenth-century literature as Canning's $(2008 ; 2012)$.

The implicatures triggered by the stylistic features and contextual aspects of Coppe's prophetic writing are analysed in their dynamic conceptual relationships. In particular, the 'recycling' of an existing network of mental spaces produces new juxtapositions and new features not available in the input spaces, with a direct effect on the structure of the analogies that can be made between mental spaces. In this way, new meaning effects which are attained open up new possibilities of perspectivizing and insinuating radically different meanings in the text, which can be interpreted as an orthodox or heterodox piece of writing at the same time.

The article will first offer a survey of those aspects of CMT and CIT that are particularly relevant for a cognitive analysis, then it will provide some necessary contextual information on the seventeenth-century cultural and religious background (which will hopefully explain why a cognitive approach is particularly fruitful for this analysis); finally, it will focus on the cognitive and ideological implications triggered by the central blend of the text, trying to show how it creates supplementary symbolizing patterns and unpredictable perlocutionary effects.

\subsection{Conceptual Metaphor Theory}

Since the ground-breaking work of Ortony (1979), Lakoff \& Johnson (1980, 1999), and Lakoff \& Turner (1989), the idea that metaphors (with all their cognitive bearings) are pervasive in human communication has been widely accepted as a matter of fact. Cognitive approaches open up new perspectives for linguistic and literary analyses by highlighting their underlying structures and, not surprisingly, CMT is now the dominant research paradigm for the analysis of metaphors as dynamic hermeneutic constructions (cf. Fludernik 2015: 169).

CMT provides clues as to the way people construct mental abstract domains by projecting a (usually concrete) source domain onto a (usually abstract) target

2 The bibliography on Conceptual Metaphor Theory and Conceptual Integration Theory is unmanageably broad. Apart from the classic studies by Ortony (1979), Lakoff \& Johnson (1980), Lakoff \& Turner (1989), Fauconnier \& Turner (1998; 2002), some relevant theoretical aspects are discussed by Fauconnier (1994; 1997), Gibbs (1994; 2008), Turner (1996), Goatly (1997), Grady, Oakley \& Coulson (1999), Coulson \& Oakley (2000; 2003; 2005), Charteris-Black (2004), Deignan (2005), Kövecses (2005; 2010), Knowles \& Moon (2006), Dancygier (2006), Lakoff (2008), Tendahl \& Gibbs (2008), Fludernik (2010), Douthwaite (2011), Forceville (2016). A critical approach similar to the one proposed here is Canning $(2008 ; 2012)$, which uses Conceptual Metaphor Theory and Conceptual Integration Theory as complementary frameworks to analyse early modern literature. 
domain, and has traditionally emphasized the role played by metaphors in providing a 'natural' cognitive model, in which abstract concepts are structured and understood through models projected from concrete source domains. CMT is, thus, particularly helpful for analysing indirect or ambiguous linguistic expressions and meanings: CMs, for example make messages vivid and compact in order to favour persuasion (cf. Goatly 1997; Charteris-Black 2004), they "provide a way of expressing ideas that would be extremely difficult to convey using literal language" (Gibbs 1994: 124-5), they may even help speakers pattern their emotional reactions (cf. Cameron 2008: 204).

Unsurprisingly, CMT has become a major analytical framework and has been profitably employed together with pragmatics and stylistics in text analysis to account for non-literal meanings and conversational implicatures: after all, as Fludernik (2010: 7) stresses, the meaning of a metaphor "does not need to be spelled out, since it is left open ... and what the results of this projection will be remains negotiable".

\subsection{Conceptual Integration Theory}

CMT, however, cannot fully explain how the mappings between domains can produce new, richer constructs from a semantic point of view. CIT tries to answer this question by offering a model of meaning construction which Turner (2002: 10) described as the combination of "two mental packets of meaning ... to create a third mental packet of meaning that has new, emergent meaning".

CIT is based on a set of mental operations which blend dynamic and temporary cognitive structures, called mental spaces, in a conceptual integration network. A blend relies on the notion of a generic space, a sort of skeletal construct which gives coherence and determines the structure of the analogies between two or more independent conceptual constructs, called input spaces. The shared structure and similarity between input elements allow for cross-space mappings which give rise to a conceptual superimposition, in which elements of the input spaces are selectively projected into a blended space. This functional interaction involves not just the fusion of existing elements, but the production of a new mental representation, an emergent structure, according to a threefold process: composition (i.e., the projection and fusion of elements from the input spaces into the blended space); completion (i.e., the introduction of supplementary notions we normally associate with the projected elements and that allow us to complete the scenario); and elaboration (i.e., the "simulated mental performance of the event in the blend, which we may continue indefinitely" and through which we "are able to imagine scenarios which unfold along various possible trajectories" (Grady, Oakley \& Coulson 1999: 107)). 
The conceptual network of temporary spaces has thus a direct effect on the structure of the analogies that can be made between mental spaces: blending can help account with greater specificity for the mapping operations that underlie the creation of any scenario; because it explains how new meanings which were not available in any of the inputs are generated. ${ }^{3}$ It can even make the same message interpretable in very different ways, because it multiplies the hermeneutic possibilities that can be established between the various spaces: as Fludernik (2010: 11) wrote, the "proliferations of meaning arising from the source domain are in fact unlimited".

\subsection{Blended spaces}

Blended spaces rely on two fundamental operations, selectivity and compression. Blends are selective because only some salient aspects of the input spaces enter the blend and only some salient structure of the blended space can be projected back to the inputs. Moreover, the basic process underlying any blending is the 'compression' into a single mental conceptualization of elements that were independent in the input spaces, or its opposite, the 'decompression' of unified concepts which are expanded and then rearranged into a new concept.

The fact that only specific elements are mapped and projected into the blend, and that they can be compressed or expanded, means that blends help clarify or enrich the meanings and implicatures of abstract concepts, but they also reinforce (or question) some established social or cultural truths. The particular configuration of mental spaces set up in a blend can thus be seen as a mechanism for projecting specific attitudinal meanings (cf. Sweetser 1996; Dancygier 2002), because the construction of meaning is strictly tied to the configurations of mental spaces.

In short, just like CMs, blends are characteristically ideological and consequently perform a crucial role in the text by providing clues as to its emotional, ideological, or evaluative points of view: ${ }^{4}$ as Dancygier (2005: 111) put it, since a mental space "is an ad hoc mental structure allowing for some understanding of a situation, then it is naturally also a locus of viewpoint".

3 Even incongruous or anomalous concepts can be understood and accepted, since, as Fludernik (2010: 15) reminds, incompatible or non-natural "storytelling frames arise from the blending of previously familiar natural or naturalized storytelling scenarios" until they have been reused sufficiently often to become recognizable and acceptable integrated conceptualizations to our mind.

$4 \quad$ On this see Simpson (1993), Herman (2002), Goatly (2007), Cameron (2008), Douthwaite (2009; 2011), Neagu (2013). 


\subsection{Cultural and religious contexts of Coppe's text}

Since blends and CMs are dependent on contextual variables, as many scholars have amply demonstrated (cf. Goatly 1997; Gibbs \& Steen 1999; Kövecses 2005, 2015), before turning to Coppe's text it is necessary to provide some cultural and religious background knowledge to present its cognitive environment but also its literary milieu; after all, Forceville (2016: 98) is explicit in stating that genre is paramount in channelling interpretations of discourse.

In seventeenth-century England, literalism had become the rallying cry of advanced Puritanism, but the so called puritan style was often very far from the "unadorned simplicity and spontaneity of common speech", so much so that "hostility to the metaphysical style never became ... hostility to the stylistic cultivation or to the constant use of figures and tropes" (Miller 1961: 304). Nonconformists, however, were harshly criticized exactly because they had transformed religion into a series of fantastic doctrines embellished with empty schemes of speech:

And herein lies the most material difference between the sober Christians of the Church of England, and our modern Sectaries, That we express the Precepts and Duties of the Gospel in plain and intelligible Terms, whilst they trifle them away by childish Metaphors and Allegories, and will not talk of Religion but in barbarous and uncouth similitudes. (Parker 1670: 75)

Yet, the distinction between literal and metaphorical was not so easy to draw, thus underscoring a fundamental, insoluble predicament in Protestant hermeneutics:

Puritan preachers conceived of literal meaning as a rhetorical construct, as a pliable figure and not a given of language. Even literal meaning was dependent on the interplay of signifiers and the use of tropes, so much so that the function of reference could depend substantially on the relation of words to each other in discourse. (Kibbey 1986: 11)

Calvin had been radical in separating this world from ultra-mundane realities (for instance, in this world there can be no miracles, such as Christ's real Eucharistic presence; likewise, bodily experiences are to be despised or, at best, can be considered as shadowy signs of the world to come); yet, the faithful were encouraged to pursue an experimental rather than doctrinal relationship with the Word of God, as archbishop Cranmer had stressed as early as 1547 in A Fruitful Exhortation to the Reading of Holy Scripture:

And in reading of God's word, he most profiteth not always that is most ready in turning of the book, or in saying of it without the book; but he that is most turned into it, that is most inspired with the Holy Ghost, most in his heart and life altered and changed into that thing which he readeth. (Griffiths 1859: 10) 
For many people, this meant to perceive divine realities as real presences in their bodies, on the basis of Paul's claim "I am crucified with Christ: nevertheless I live; yet not I, but Christ liveth in me". ${ }^{5}$ In England, radical groups were eager to interpret metaphorical expressions in a literal sense and to transform the inward aspect of religion into an outward, bodily experience, ${ }^{6}$ with clear political implications. Not surprisingly, the 1640 s and the 1650 s were characterized by an onslaught against 'abominable practices', 'horrid blasphemies', or 'abuses of the Scriptures' produced by a hyper-realistic interpretation of religious tenets.

Literalism and figuration had become so inextricably tied in Protestant hermeneutics that, as Luxon (1995: 190) writes: "Since the truly real is everything on the other side of the 'things of this world', what this world understands as realism is, strictly speaking, allegory. The more 'realistic' the story sounds, the more thoroughly allegorical it is". So, in many cases the attack against metaphors ended up promoting a literalism which paradoxically verged on metaphorical 'distortions' and ultimately ignored the distinction between this world and the next. If to claim that one was the spouse of Christ was not a metaphor anymore because the real body was the spiritual one; or if the true believer was a 'living allegory' (Mack 1982: 30) whose carnal body-as-flesh was just a metaphor of the true spiritual body, then the more metaphorical you were, the more authentic and literal you were.

The consequences of this dualistic, aporetic ontology have to be taken into consideration when analysing a genre, such as seventeenth-century prophetic writing, which basically relied on the fact that the metaphorical was the literal, or that true reality was otherworldly and thus only metaphorically describable. It is a perspective that fits perfectly with the idea that, as CMT asserts, our mind and our language are inherently metaphorical or that metaphors are not exceptions or special ways of thinking/writing.

\subsection{Abiezer Coppe}

Abiezer Coppe (1619-1672?) ${ }^{7}$ was one of the most notorious radical preachers during the Civil War. In 1647, he claimed that a mystical experience had allegedly

5 Galatians 2: 20. This and all the following quotations from the Bible are from the King James Version.

6 For example, the notorious William Franklin, a married man who in July 1649 had solemnly proclaimed that his outward body had been totally replaced with Christ's spiritual body, regularly slept with Mary Gadbury, a married and deserted woman who maintained that she was the 'Spouse of Christ' and, more importantly, that her relation with Franklin was not carnal but spiritual, Franklin's body being by definition no more a concrete fleshly body but a glorified spiritual body. On the radical 'appropriations' of the Scriptures, the classic studies by Hill (1972) and Mack (1982) are still fundamental.

$7 \quad$ For more information on Coppe and his writings see Hill (1972; 1982), Hopton (1987), Smith (1989), Corns (1992), McDowell (1997; 2003; 2012), Hessayon (2004; 2011), Pick (2009). 
transformed him into 'a child of God' to whom the restrictions of conventional society no longer applied. In 1649 Coppe published a controversial radical tract, A Fiery Flying Roll, an apocalyptic prediction in two parts which envisioned the overthrow of the existing social order and questioned orthodox religious truths. The pamphlet was immediately banned and Coppe was imprisoned without trial in January 1650 (Parliament issued the Blasphemy Act a few months later).

After some months in jail, Coppe wrote A Remonstrance, a short letter of protestation which, however, failed to gain him liberty, so he wrote $C R$, a longer and more detailed plea made up of five parts. It begins with a Preface addressed to the Parliament "shewing What the Author hath been, and now is" and insisting on the disproportionate harshness of his imprisonment; then, there is a long section in which Coppe presents his own theological "Errors" and then confutes them in truthful "Assertions" ("Truth asserted against, and Triumphing over Error"); the third part is the letter which one of his inquisitors, Reverend John Dury, sent to Coppe ("The Preamble to the ensuing Proposals", followed by Coppe's answer ("The Answer of A.C. to Mr Duries Proposals"). The concluding section is a letter to Marchamont Nedham, who acted as "spokesman" for the Commonwealth regime ("A.C. his letter to his Much Honoured Friend, Mr. Marchamont Nedham").

Coppe's main aim was of course to convince the authorities to set him free and, apparently, his recantation was successful: after further examination, he was released at the end of June 1651, even though many of his contemporaries were not convinced of his sincerity and thought he was just pretending repentance. However, the text presents some 'eccentric' arguments that seem to sneak in alternative interpretations and implicatures (Borgogni 2016) which are worth analysing in detail. Since a complete examination of Coppe's tract is beyond the limits of an article, the following discussion will advance a possible interpretation of Coppe's real intentions by focusing on what is allowedly the central metaphorical image in the text, analysing its implications in the light of CIT.

\section{Discussion}

Among the accusations levelled at Coppe, Reverend John Dury had insisted on the fact that the preacher had denied the existence of sin for the redeemed and claimed that sinful actions were the nearest way to perfection. He had thus invited Coppe to make amends without dissembling repentance, so that his former opinions might be fully disavowed and his seditious booklet completely discredited. In order to reinforce his exhortation, Dury had resorted to two rather common CMs stressing that SIN IS MIRE and SIN IS A STAIN: ${ }^{8}$

8 By relying on well-known traditional expressions, Dury’s metaphors confirm Kövecses's idea 
... make not a fair profession of being effectually converted only to gain your liberty; that then as a Sow, you may return again to wallow in the mire. I say, it will be very expedient, that you clear up these things, both to yourself and to other men.

(Coppe 1651: 16)

In respect of the grievousness, and heinousness of the actions in themselves, they being of a very deep dye; you ought to wipe them away with the greater contrition before God.

(Coppe 1651: 17)

Coppe did not explicitly answer these CMs, but, after the initial and moving Preface addressed to Parliament, he started his recantation with a long Assertion that should confute the most serious of his Errors: That there is no sinne. He fills four pages with a visionary and wild discussion, harping on about the universality of sin and suggesting that what counts as sin is largely dependent on what people imagine sin to be. He then adds a final remark:

And let this, as also divers other things in the following Assertions, serve as sharp shears to clip the wings of the Fiery flying Role: which insinuates several blasphemous opinions, and which insinuates that nothing is otherwise a sin, then as men imagine it to themselves to be so: Which - I utterly disown, and protest against, (as may be more fully seen in my answer to Mr. Duries Proposal to me concerning $\sin , \& c$.).

Wherefore I say, let the wings of the Fiery flying Role, be clipt (by this large tract concerning sin, and by that which follows; with my answer to Mr. Dury) and let it be thrown headlong into its own place, the Lake of fire and brimston, and the great Abyss from whence it came.

And let me mourn that I, and the whole world lie in darkness, and are involved in Sin and wickedness

(Coppe 1651: 6)

The metaphorical blend of the winged text was not invented by Coppe: it is taken from the prophet Zechariah 5:1 ("Then I turned, and lifted up mine eyes, and looked, and behold a flying roll"), and had also been used in the first book of Christian emblems by Montenay (1571: 72). However, the insertion of other inputs (the clipping space, the damnation space) transforms it into a multiple blend, in which "either several inputs are projected in parallel, or they are projected successively into intermediate blends, which themselves serve as further inputs to further blends" (Fauconnier \& Turner 2002: 279).

(2010: 45) that a metaphor "can give us a generic-level interpretation of a specific-level proverb and then allows us to apply the generic interpretation to a specific case that has the appropriate underlying generic structure". Space constraints prevent a more elaborate discussion on the concept of sin, in particular the implications of the basic metaphors of 'stain' and 'mire' which qualify it and which would be worth analyzing in more detail. 
As a matter of fact, the real act of censuring and discrediting the pamphlet is metaphorically reconfigured by the compression of elements (a booklet with clipped wings; the lake of fire and brimstone) and then inserted into the image schema of downward movement (the abyss). This not only highlights the experiential structure of the blend (cf. Forceville 2016), but clearly alludes to the condemnation of the libel by exploiting such traditional metonymies as ABYSS AS HELL and FIRE AND BRIMSTONE AS DIVINE WRATH (see Genesis 19, Deuteronomy 29, Psalm 11:6, Revelation 19-21). The negative implicatures of these allusions are confirmed by the asymmetric topicality of the blend: only one of the inputs is topical while the other allows the re-framing of the first for communicative purposes. This means that the book is the actual focus and the blend is interested in conceptualizing or describing some specific aspects of the book, not in understanding more about wings.

However, the new structure emerging from the blend and the 'contextual implications' (Sperber \& Wilson 1995: 109) of Coppe's recantation, especially the fact that prophetic writing invited a layered reading which should have 'literal' effects on the real life of people, makes the passage a lot more ambiguous and polysemic, advancing the possibility of what Brandt \& Brandt (2005: 118) termed 'recycling', that is the reuse of the same network of mental spaces to open up new possibilities of perspectivizing and insinuating radically different ideas.

The idea of the winged text introduces the idea of a piece of writing flying up high and being hard to pin down, enjoying a freedom of movement which is dramatically interrupted by clipping. However, clipping also evokes a different meaning thanks to the biblical echo which is present in act of pruning: 'I am the true vine, and my Father is the husbandman. Every branch in me that beareth not fruit he taketh away: and every branch that beareth fruit, he purgeth it, that it may bring forth more fruit' (John 15:1-2). Paradoxically, the apparent diminution implied by the action of cutting the wings of the book and blocking its freedom of movement may result in making those wings stronger so that the tract itself may reach an increasing number of people.

Likewise, the literal act of throwing the pamphlet down into the fire and into the abyss may also imply the paradoxical fictive motion of sending the text back to a place that is somehow connected to God's omnipotence: as a matter of fact, fire and brimstone were not only the signs of God's wrath, but also divine purifying agents. The same ambiguity characterizes the abyss, whose depth is often used to allude to God's mysterious and inscrutable judgement. ${ }^{9}$

9 See Isaiah 30:33: "the breath of the LORD, like a stream of brimstone, doth kindle it."; Psalm 36:6: "Thy righteousness is like the great mountains; thy judgments are a great deep: $\mathrm{O}$ LORD, thou preservest man and beast"; Psalm 78: 15: "He clave the rocks in the wilderness, and gave them drink as out of the great depths"; Proverbs 8:27-28: "When he prepared the heavens, I was there: when he set a compass upon the face of the depth. When he established the clouds above: when he strengthened the fountains of the deep". 
In other words, while compressing some elements to produce the striking image of a reviled booklet to be wiped out, the blend also decompresses biblical allusions as unified concepts and rearranges them to trigger other implicatures. By reprocessing the existing network of mental spaces, the blend enters a new stage: it performs a double function by professing a religious stance while alluding to another, thus activating a new schema in which the clipping of the wings may bolster the tract's prophetic quality and the lake of fire and brimstone and the abyss may portend divine presence.

The different readings produced by the presence of multiple blends are confirmed by a different dynamic as to optimality principles: ${ }^{10}$ the 'orthodox' reading of the blend seems to conform easily to integration (the clipped-wing libel representation is compact and easy to manipulate), topology (the relations in the blended space correspond to the relations in the input spaces), and web (the mappings between the elements in the input spaces and those in the blend are consistent). The unpacking principle, too, is fulfilled because of the conventional metonymic mapping between clipping and destroying.

On the contrary, the 'prophetic' reading seems to rely mainly on different mappings between the elements in the blended space and those in the input spaces (thus violating the web principle) and, above all, on the disanalogous mappings between clipping the wings of the book and hurling it down into fire and giving it new life and power (thus violating the topology principle). This, in turn, problematizes the unpacking principle, since the prophetic reading of the blend produces a counterfactual reconstruction of the inputs and their network connections.

It is worth remembering that in every successful blend these principles compete and cooperate in various degrees and can thus be satisfied only to some extent. This means that the differences discussed here are not absolute but just a question of degree and relative prevalence of some over others. As a consequence, the different satisfaction of optimality principles should be considered not as a way to evaluate the exact extent to which each of the

10 Fauconnier \& Turner (1998) identified some selective and sometimes mutually incompatible constraints which increase the effectiveness of blends and favor a functional interaction between mental spaces: integration (representations in the blended space should be well integrated to be manipulated as a single unit); web (representations in the blended space should keep a tight connection with those in the input spaces and, conversely, an event in the input spaces implies a corresponding event in the blend); unpacking (starting from the blend an interpreter should easily infer and reconstruct the inputs and the conceptual network); topology (relations between elements in the blend should have the same relations as their counterparts in the input spaces); good reason (every element included in the blend should have meaning). Grady et al. (1999: 107-108) also suggest include the additional principle of metonymic tightening (related elements from the input spaces should be compressed and closely associated when they are projected into the blend). 
principles is satisfied, but to appreciate the different ideological perspective they give to the text. In particular, the features and implicatures of Coppe's text clearly grant an orthodox interpretation of the blend, but at the same time its construction and mapping possibilities also stimulate an alternative interpretation.

These two possible readings of the blend also entail a different dynamic within the network spaces: the 'orthodox' reading (see figure 1) has only one direction: the input spaces set up clear-cut correspondences (clipping is maiming, the book is a metonymy for its author, fire and abyss prefigure damnation), which are projected into the blend to anticipate the return to order (i.e., Coppe will be discredited as prophet, the dangerous ideas spread by the Fiery Flying Roll will be disowned, etc.):

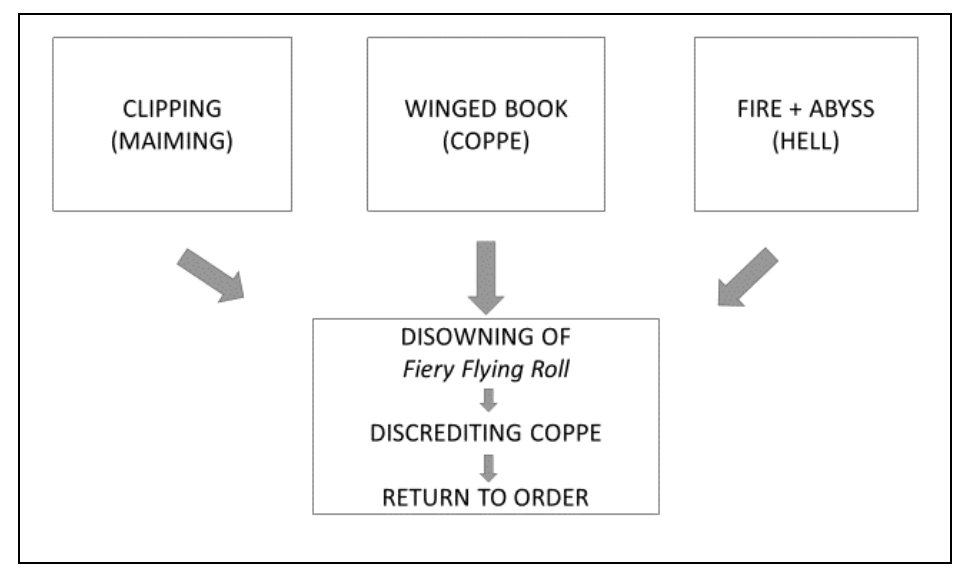

Figure 1.

The 'prophetic' reading, on the contrary, implies a double direction, ${ }^{11}$ because the correspondences projected on the blend do not have a single direction, but reverberate back to the input spaces, retrospectively modifying their implicatures. Clipping, for example, also means strengthening in order to help bear more fruit, while fire and abyss may prefigure God's presence and strength. As a consequence, the dynamic within the network spaces appears a lot more flexible and, more importantly, implies that the Fiery Flying Roll might have been divinely inspired and could spread positive ideas (see figure 2):

11 As Coulson (2001: 178-183) pointed out, some blends project inferences in more than one direction and allow people to draw inferences in either direction within a single conceptual integration network, even focusing retroactively on specific aspects of each input. 


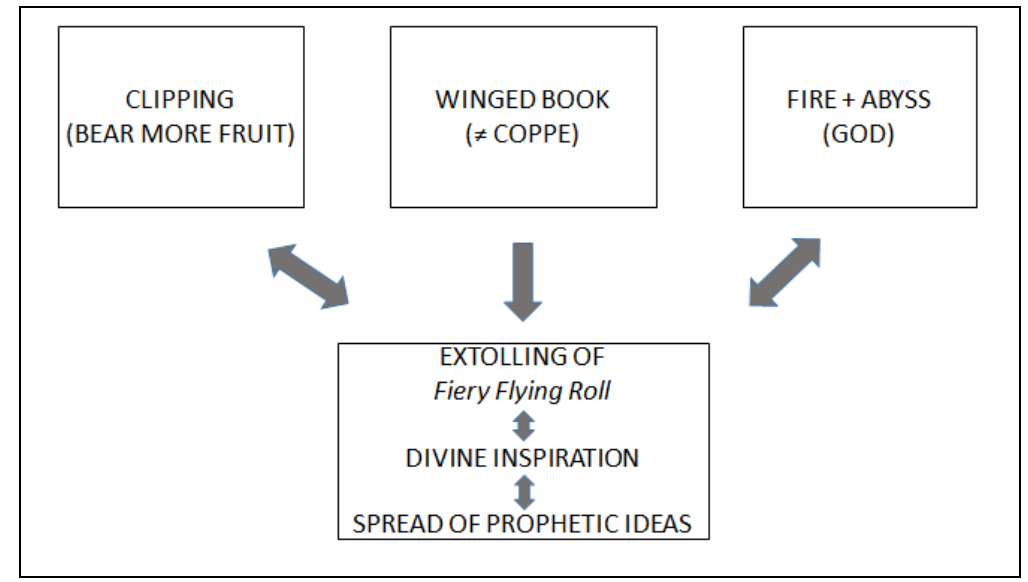

Figure 2 .

The cognitive perspective of CIT shows that Coppe was able to produce an assertion that appeared irrefutable and theologically sound, but that at the same time was rich enough in weak implicatures (cf. Sperber \& Wilson 1995) to arouse a very different ideological perspective, at least in those readers whose hermeneutic abilities were refined enough to appreciate it.

The argumentative subtlety and the implicatures triggered by the blend seem to confirm the impression that Coppe might have an ambitious though risky strategy in mind: his main aim was of course to regain his liberty, but also to prevent the stigmatization of his prophetic writings. As a matter of fact, while Dury had resorted to common CMs to establish a metonymic association between Coppe and his book, $C R$ reveals Coppe's attempt to break the ideological metonymy BOOK AS AUTHOR which implied a necessary identification between the tract and its author. He presents himself and his tract as two separate entities (he hopes his Assertion will 'serve as sharp shears to clip the wings' of the Fiery Flying Roll and throw it into Hell), and explicitly dissociates his liberation from the censorship of his libel, basically suggesting that, if he deserved to be set free, he should be released irrespective of the clipping and burning of his Fiery Flying Roll. In this way, Coppe invites his readers to 'run the blend' and realize that the attempt to discredit and suppress his writing in fact attests to its relevance.

This impression is reinforced by the already quoted conclusion of the Assertion: "And let me mourn that I and the whole world lie in darkness, and are involved in Sin and wickedness" (Coppe 1651: 6). What does the speaking voice mourn for? How can the world (and Coppe) 'lie in darkness' and be surrounded by 'Sin and wickedness' if such a decisive action as destroying the dangerous and seditious text has just been accomplished? The most obvious, 
orthodox answer would be that grief is the consequence of realizing that $\sin$ is universal and casts its shadow on the world. However, a 'prophetic' reading is also possible, as the sentence relies on a temporal blending (see figure 3 ) in which the future scenario of a world where Coppe's book is destroyed is described as the present, mournful scenario of living in darkness and being involved in sin and wickedness.

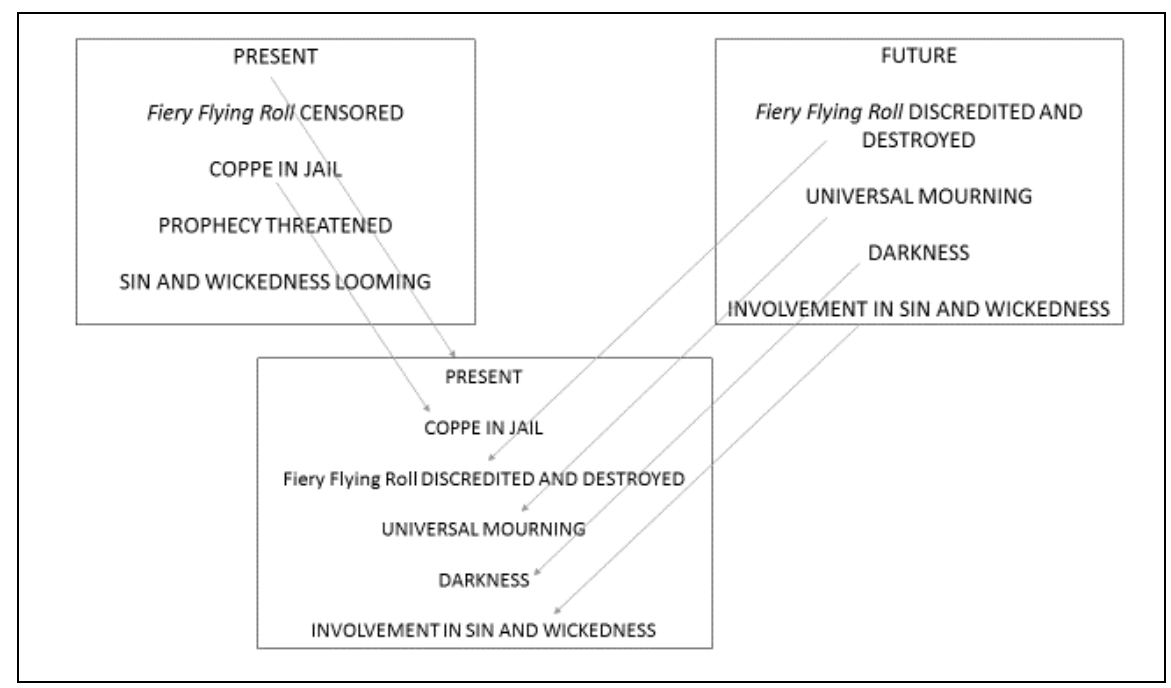

Figure 3.

Thanks to the powerful inversion of the cause-effect relation in this blended temporal space, the catastrophic consequences of eliminating the Fiery Flying Roll are not only anticipated but dramatically felt in the present as the death of truth and the dominance of obscurantist forces, a tragic perspective which is not recruited from the input spaces but is the result of the emergent structure of the blend which reverberates back on the input spaces.

This retroactive effect of Coppe's blending has dramatic consequences on the nature and meaning of Coppe's assertions. Dury's letter contained an explicit request to explain thoroughly "Whether any thing be otherwise a sin, then as men imagine it to themselves to bee so" (Coppe 1651: 16) and, as we have seen in a passage already quoted above, Coppe hoped that his text might be a convincing recantation of such blasphemous opinions as that "nothing is otherwise a sin, then as men imagine it to themselves to be so" (Coppe 1651: 6).

However, the final part of the text repeatedly takes up Dury's invitation transforming it into something completely different: 
I say, and know, that drunkenness of all sorts, theft of all sorts, and murther of all sorts, is a sin.

Whether men imagine it to be so, or no.

And so is pride, covetousness, hypocrisie, oppression, Tyranny, cruelty, unmercifulnesse, despising the poor and the needy, who are in vile raiment, \&c. * Jam.2.

A sin.

Whether men imagine it to be so, or no.

...

And the laying of Nets, Traps and Snares for the feet of our neighbours, is a sin.

Whether men imagine it to be so, or no.

And so is the not undoing of heavy burthens, the not letting the oppressed go free, the not breaking every yoak, and the not dealing of bread to the hungry, \&c. and the hiding our selves from our own flesh, \& c.

A sin.

Whether men imagine it to be so, or no.

(Coppe 1651: 21)

Repetitions are often a hallmark of religious texts, and may serve as stylistic internal norms to stress particularly important concepts and help their transmission to an audience. In Coppe's tract, however, Dury's words (Whether men imagine it to be so become an obsessive refrain, a dazzling series of thirteen repetitions in seventy-four textual lines which inevitably transform them into a hollow catchphrase. So, if repetitions are to be expected in a religious text as a matter of fact, their compulsive presence becomes an echoic repetition which seems "primarily designed to ridicule the opinion echoed" (Sperber \& Wilson 1995: 241).

Coppe, then, resorts to a typical stylistic feature of religious rhetoric which apparently demonstrates his willingness to comply with Dury's recommendations. At the same time, however, he overuses and distorts it to produce unpredictable ideological effects on his readers: Dury's echoed opinion is ultimately spurned and becomes a sort of metastatic presence in the text to denounce a number of social evils, from "theft" to "oppression", from "the not letting the oppressed go free", to "the not dealing of bread to the hungry".

In short, one does not have the impression that Coppe "utterly disowned and protested against" sin, but that he was up to something more ambitious and complex which reminds one of what Dancygier (2005: 120) termed 'viewpoint compression': the framework of seventeenth-century religious and cultural tenets remains and retains its global function, but the blended space set up in the text allows the coexistence in the network of two seemingly incompatible mental representations of Coppe as the penitent sinner hoping to be released and Coppe as the radical preacher who keeps his prophetic and ironical stance. Only blending allows such a compression of conflicting points of view, and the fusion of imagination and reality does not appear as an arbitrary or odd practice; on the contrary, it makes the narrative more stimulating for readers. 


\section{Conclusion}

The analysis of $C R$ from a linguistic and cognitive perspective highlights the multi-layered nature of Coppe's prophetic recantation and the hermeneutic complexity it stimulates. The implicatures triggered by the central blend of the text account not only for the production of new features which were not available in the input spaces, but also mean that the results of the projections in the network of mental spaces remain negotiable. They allow different interpretations of wellestablished religious categories and ultimately make the text sound plausibly orthodox but, at the same time, ambiguous enough to generate supplementary symbolizing patterns and alternative interpretations.

The purpose of this strategy, however, is not to spread equivocation; rather, Coppe seems interested in meeting a double commitment, producing an acceptable plea for his former 'sins' but also putting forward a sort of statement of principle as to his life and ideas. In this way, the radical preacher managed to appease the authorities and regain his liberty - Coppe was eventually released, maybe "on compassionate grounds, as he was believed to be insane" (McEnery 2006: 66) - but at the same time he was able to propose a new, albeit indirect, way of social bonding. By stimulating his fellow followers to pursue the implicatures of the emergent structure of the blends, his text was able to insinuate additional meanings with unpredictable perlocutionary effects, even though the theological implications of such a strategy were carefully and precautionarily left to the understanding of the single reader.

In conclusion, analysing $C R$ from a cognitive perspective cannot offer a definitive explanation of Coppe's intention, nor prove the sincerity of his repentance, but allows for an objective discussion of Coppe's text and stimulates an evaluation of its ideological bearing on the seething religious milieu of midseventeenth-century England.

\section{REFERENCES}

\section{PRIMARY SOURCES}

Coppe, Abiezer. 1651. Copp's return to the wayes of truth: in a zealous and sincere protestation against severall errors; and in a sincere and zealous testimony to severall truths: or, truth asserted against, and triumphing over error; and the wings of the fiery flying roll clipt, \&c. London: Printed by Tho. Newcomb.

Griffiths, John (ed.). 1859. The two books of homilies appointed to be read in churches. Oxford: Oxford University Press. 
Hopton, Andrew (ed.). 1987. Selected writings of Abiezer Coppe. London: Aporia Press.

The Holy Bible, containing the Old and New Testaments, translated out of the original tongues : and with the former translations diligently compared and revised by his majesty's special command. Authorized King James Version.

https://www.kingjamesbibleonline.org/

Montenay, Georgette de. 1571. Emblemes ou devises chrestiennes. Lyons: Jean Marcorelle.

Parker, Samuel. 1670. A discourse of ecclesiastical politie: wherein the authority of the civil magistrate over the consciences of subjects in matters of external religion is asserted; the mischiefs and inconveniences of toleration are represented, and all pretenses pleaded in behalf of liberty of conscience are fully answered. London: Printed for John Martyn at the Bell without Temple-Bar.

\section{SECONDARY SOURCES}

Borgogni, Daniele. 2016. Recanting errors, asserting truths: Ideology and modality in Abiezer Coppe's Copp's return to the wayes of truth. Journal of Advances in Linguistics 6(2). 977-993.

Brandt, Line \& Per Aage Brandt. 2005. Cognitive poetics and imagery. European Journal of English Studies 9(2). 117-130. DOI: 10.1080/13825570500171861

Cameron, Lynne. 2008. Metaphor and talk. In Raymond W. Gibbs, Jr. (ed.), The Cambridge handbook of metaphor and thought, 197-211. Cambridge: Cambridge University Press.

Canning, Patricia. 2008. 'The bodie and the letters both': 'Blending' the rules of early modern religion. Language and Literature 17(3). 187-203. DOI: 10.1177/0963947008092499

Canning, Patricia. 2012. Style in the Renaissance: Language and ideology in Early Modern England. London \& New York: Continuum.

Charteris-Black, Jonathan. 2004. Corpus approaches to critical metaphor analysis. Houndmills: Palgrave.

Corns, Thomas. 1992. Uncloistered virtue: English political literature, 1640-1660. Oxford: Oxford University Press. DOI: 10.1093/acprof:oso/9780198128830.001.0001

Coulson, Seana. 2001. Semantic leaps. Frame-shifting and conceptual blending in meaning construction. New York \& Cambridge: Cambridge University Press.

Coulson, Seana \& Todd Oakley. 2000. Blending basics. Cognitive Linguistics 11(3-4). 175-196. DOI: $10.1515 / \operatorname{cog} 1.2001 .014$

Coulson, Seana \& Todd Oakley. 2003. Metonymy and conceptual blending. In Klaus-Uwe Panther \& Linda L. Thornburg (eds.), Metonymy and pragmatic inferencing, 51-79. Amsterdam \& Philadelphia: John Benjamins. DOI: 10.1075/pbns.113.06cou

Coulson, Seana \& Todd Oakley (eds.). 2005. Journal of Pragmatics 37(10). Special issue on Conceptual Integration Theory.

Dancygier, Barbara. 2002. Mental space. Embeddings, counterfactuality, and the use of unless. English Language and Linguistics 6(2). 347-377. DOI: 10.1017/S1360674302000278

Dancygier, Barbara. 2005. Blending and narrative viewpoint: Jonathan Raban's travels through mental spaces. Language and Literature 14(2). 99-127. DOI: $10.1177 / 0963947005051281$ 
Dancygier, Barbara. 2006. What can blending do for you? Language and Literature 15(1). 5-15. DOI: $10.1177 / 0963947006060549$

Deignan, Alice. 2005. Metaphor and corpus linguistics. Amsterdam: John Benjamins. DOI: 10.1075/celcr.6

Douthwaite, John. 2009. Pragmatic patterning in the deployment of conceptual metaphor and communication. Plurilinguismo 16. 83-117.

Douthwaite, John. 2011. Conceptual metaphor and communication: An Austinian and Gricean analysis of Brian Clark's Whose life is it anyway? In Monika Fludernik (ed.), Beyond cognitive metaphor theory: Perspectives on literary metaphor, 137-157. New York: Routledge.

Fauconnier, Gilles. 1994. Mental spaces: Aspects of meaning construction in natural language. (2nd edn.) Cambridge: Cambridge University Press.

Fauconnier, Gilles. 1997. Mappings in thought and language. Cambridge: Cambridge University Press. DOI: $10.1017 /$ CBO9781139174220

Fauconnier, Gilles \& Mark Turner. 1998. Conceptual integration networks. Cognitive Science 22(2). 133-187. DOI: 10.1207/s15516709 $\operatorname{cog} 2202 \_1$

Fauconnier, Gilles \& Mark Turner. 2002. The way we think: Conceptual blending and the mind's hidden complexities. New York: Basic Books.

Fludernik, Monika. 2010. Naturalizing the unnatural: A view from blending theory. Journal of Literary Semantics 39. 1-27. DOI: 10.1515/j1se.2010.001

Fludernik, Monika. 2015. Blending in cartoons: The production of comedy. In Lisa Zunshine (ed.), The Oxford handbook of cognitive literary studies, 155-175. Oxford: Oxford University Press. DOI: 10.1093/oxfordhb/9780199978069.013.0009

Forceville, Charles. 2016. Conceptual metaphor theory, blending theory, and other cognitivist perspectives on comics. In Neil Cohn (ed.), The visual narrative reader, 89-114. London: Bloomsbury.

Gibbs, Raymond W., Jr. 1994. The poetics of mind. Cambridge: Cambridge University Press.

Gibbs, Raymond W., Jr. (ed.). 2008. The Cambridge handbook of metaphor and thought. Cambridge: Cambridge University Press.

Gibbs, Raymond W., Jr. \& Gerard Steen (eds.). 1999. Metaphor in cognitive linguistics. Selected papers from the 5th International Cognitive Linguistics Conference, Amsterdam, 1997. Amsterdam and Philadelphia: John Benjamins. DOI: 10.1075/cilt.175

Goatly, Andrew. 1997. The language of metaphors. London: Routledge.

Goatly, Andrew. 2007. Washing the brain. Metaphor and hidden ideology. Amsterdam \& Philadelphia: John Benjamins. DOI: 10.1075/dapsac.23

Grady, Joseph, Todd Oakley \& Seana Coulson. 1999. Blending and metaphor. In Raymond W. Gibbs, Jr. \& Gerard Steen (eds.), Metaphor in cognitive linguistics. Selected papers from the 5th International Cognitive Linguistics Conference, Amsterdam, 1997, 100124. Amsterdam \& Philadelphia: John Benjamins. DOI: 10.1075/cilt.175.07gra

Herman, David. 2002. Story logic. Problems and possibilities of narrative. Lincoln: University of Nebraska Press.

Hessayon, Ariel. 2004. Coppe, Abiezer (1619-1672?). In Oxford dictionary of national biography. Oxford: Oxford University Press. http://www.oxforddnb.com/view/article/6275 DOI: 10.1093/ref:odnb/6275

Hessayon, Ariel. 2011. The making of Abiezer Coppe. Journal of Ecclesiastical History 62(1). 3858. DOI: $10.1017 / \mathrm{S} 0022046909991333$ 
Hill, Christopher. 1972. The world turned upside down. Radical ideas during the English revolution. London: Temple Smith.

Hill, Christopher. 1982. Radical prose in seventeenth-century England. Essays in Criticism 32. 95118.

Kibbey, Ann. 1986. The interpretation of material shapes in Puritanism. A study of rhetoric, prejudice, and violence. Cambridge: Cambridge University Press.

Knowles, Murray \& Rosamund Moon. 2006. Introducing metaphor. London: Routledge.

Kövecses, Zoltán. 2005. Metaphor in culture. Universality and variation. Cambridge: Cambridge University Press.

Kövecses, Zoltán. 2010. Metaphor. A practical introduction. (2nd edn.) Oxford: Oxford University Press.

Kövecses, Zoltán. 2015. Where metaphors come from. Reconsidering context in metaphors. Oxford: Oxford University Press.

Lakoff, George. 2008. The neural theory of metaphor. In Raymond W. Gibbs, Jr. (ed.), The Cambridge handbook of metaphor and thought, 17-38. Cambridge: Cambridge University Press. DOI: 10.1017/CBO9780511816802.003

Lakoff, George \& Mark Johnson. 1980. Metaphors we live by. Chicago: University of Chicago Press.

Lakoff, George \& Mark Johnson. 1999. Philosophy in the flesh: The embodied mind and its challenge to western thought. New York: Basic Books.

Lakoff, George \& Mark Turner. 1989. More than cool reason. Chicago: University of Chicago Press.

Luxon, Thomas. 1995. Literal figures: Puritan allegory and the Reformation crisis in representation. Chicago \& London: University of Chicago Press.

Mack, Phyllis. 1982. Women prophets during the English Civil War. Feminist Studies 8. 19-45. DOI: $10.2307 / 3177578$

McDowell, Nicholas. 1997. A ranter reconsidered: Abiezer Coppe and civil war stereotypes. Seventeenth Century 12. 173-205. DOI: 10.1080/0268117X.1997.10555429

McDowell, Nicholas. 2003. English radical imagination: Culture, religion, and revolution, 16301660. Oxford: Oxford University Press. DOI: 10.1093/acprof:oso/9780199260515.001.0001

McDowell, Nicholas. 2012. Abiezer Coppe. In Garret A. Sullivan, Jr. \& Alan Stewart (eds.), The encyclopedia of English Renaissance literature: A-F, Vol. 1, 212-214. Oxford: Wiley Blackwell.

McEnery, Tony. 2006. Swearing in English: Bad language, purity and power from 1586 to the present. London \& New York: Routledge.

Miller, Perry. 1961. The New England mind: The seventeenth century. Boston: Beacon Press.

Neagu, Maria-Ionela. 2013. Decoding political discourse: Conceptual metaphors and argumentation. Basingstoke: Palgrave Macmillan.

Ortony, Andrew (ed.). 1979. Metaphor and thought. Cambridge: Cambridge University Press.

Pick, Peter. 2009. A theology of revolutions. Abiezer Coppe and the uses of tradition. In Alexandre J. M. E. Christoyannopoulos (ed.), Religious anarchism: New perspectives, 30-46. Cambridge Scholars Publishing: Newcastle-upon-Tyne.

Simpson, Paul. 1993. Language, ideology and point of view. London: Routledge.

Smith, Nigel. 1989. Perfection proclaimed: Language and literature in English radical religion, 1640-1660. Oxford: Oxford University Press. 
Sperber, Dan \& Deirdre Wilson. 1995. Relevance. Communication and cognition. (2nd edn.) Oxford: Blackwell.

Sweetser, Eve. 1996. Mental spaces and the grammar of conditional constructions. In Gilles Fauconnier \& Eve Sweetser (eds.), Spaces, worlds, and grammars, 318-333. Chicago: University of Chicago Press.

Tendahl, Markus \& Raymond W. Gibbs, Jr. 2008. Complementary perspectives on metaphor: cognitive linguistics and relevance theory. Journal of Pragmatics 40. 1823-1864. DOI: 10.1016/j.pragma.2008.02.001

Turner, Mark. 1996. The literary mind: The origins of language and thought. Oxford: Oxford University Press.

Turner, Mark. 2002. The cognitive study of art, language and literature. Poetics Today 23(1). 9-20. DOI: $10.1215 / 03335372-23-1-9$ 